\title{
PENGEMBANGAN APLIKASI MATERIAL LIMBAH PELEPAH KELAPA SAWIT UNTUK PRODUK AKSESORIS INTERIOR
}

\author{
${ }^{1}$ Al Issya Suci Rachmawati, ${ }^{2}$ Dita Andansari \\ ${ }^{1}$ Mahasiswa Prodi. Desain Produk, Jurusan Desain \\ ${ }^{2}$ Staf Pengajar Prodi. Desain Produk,Jurusan Desain (ditaandansari@yahoo.com) \\ Politeknik Negeri Samarinda, Jl. Dr. Ciptomangunkusumo Kampus Gunung Lipan \\ Po. Box. 1293, Samarinda 75131
}

\begin{abstract}
ABSTRAK
Tanaman kelapa sawit merupakan salah satu jenis tanaman perkebunan yang menduduki posisi penting dalam sektor pertanian dan sektor perkebunan terutama di daerah Provinsi Kalimantan Timur. Sejalan dengan semakin meningkatnya produksi kelapa sawit dari tahun ke tahun, di sisi lain akan terjadi pula peningkatan volume limbahnya. Sebelumnya, telah dilakukan penelitian terhadap limbah pelepah kelapa sawit yang dapat dijadikan sebagai material utama dalam pembuatan produk fungsional seperti produk pewadahan, lampu dan juga kerai yang melalui proses ditenun. Belum dilakukan pengembangan dengan proses yang lain seperti dianyam. Penelitiaan kali ini mengembangkan material limbah pelepah kelapa sawit dengan cara dianyam. Metode perancangan yang dilakukan yaitu melakukan pengumpulan data, analisa data, menentukan konsep desain, membuat desain alternatif, mengembangkan desain alternatif, hingga desain akhir. Eksplorasi lanjutan terhadap limbah pelepah kelapa sawit dengan cara dianyam ini membuka peluang untuk mengembangkan dan mengeksplorasi lebih jauh terhadap limbah pelepah kelapa sawit menjadi sebuah produk fungsional yang memiliki nilai jual. Ekplorasi dilakukan untuk mengetahui kemampuan limbah yang awalnya hanya bisa ditenun, maka kini setelah dilakukan ekplorasi diketahui bahwa limbah juga dapat dianyam dengan beberapa pola tertentu, mulai dari pola sederhana dan juga pola melingkar.
\end{abstract}

Kata kunci : limbah, pelepah kelapa sawit, pemanfaatan, produk aksesoris interior, anyaman 
Al Issya Suci Rachmawati, Dita Andansari, Pengembangan Aplikasi Material Limbah Pelepah Kelapa Sawit Untuk Produk Aksesoris Interior

\section{ABSTRACT}

Oil palm is one of the types of plantation crops that occupy an important position in the agricultural and plantation sectors, especially in the province of East Kalimantan. In line with the increasing production of palm oil from year to year, on the other hand there will also be an increase in the volume of its waste. Previously, research had been carried out on oil palm frond waste which could be used as the main material in the manufacture of functional products, such as container products, lamps and blinds through the weaving process. There has not been any development with other processes such as weaving. This research is developing palm oil waste material by weaving it. The design method used is to collect data, analyze data, determine design concepts, create alternative designs, develop alternative designs, to the final design. Continued exploration of oil palm frond waste by weaving opens opportunities to develop and further explore palm oil frond waste into a functional product that has a sale value. Exploration was carried out to determine the ability of the waste which initially could only be woven, so now after exploration it is known that waste can also be woven in certain patterns, starting from simple patterns and also circular patterns.

Keywords: waste, palm fronds, utilization, interior accessories products, woven

\section{PENDAHULUAN}

Tanaman kelapa sawit merupakan salah satu jenis tanaman perkebunan yang menduduki posisi penting dalam sektor pertanian dan sektor perkebunan.Kelapa sawit merupakan komoditi andalan Indonesia yang perkembangannya demikian pesat. Lahan optimal untuk kelapa sawit harus mengacu pada tiga faktor yaitu lingkungan, sifat fisik lahan dan sifat fisik kimia tanah atau kesuburan tanah.Tanaman kelapa sawit di perkebunan komersial dapat tumbuh dengan baik pada kisaran suhu 24-28 derajat celcius.Untuk memperoleh hasil maksimal dalam budidaya kelapa sawit perlu memperhatikan sifat fisik dan kimia tanah diantaranya struktur tanah dan drainase tanah baik (Pahan, 2006).

Menurut Ujang Rachmad selaku Kepala Dinas Perkebunan Kalimantan Timur, luas perkebunan kelapa sawit terus mengalami peningkatan yang signifikan dan hingga akhir 2017 sudah mencapai 1.208.697 hektar (1,2 juta hektar).Perkebunan sawit tersebut meliputi 10 kabupaten dan kota di Kaltim dengan luasan terbesar di Kabupaten Kutai Timur mencapai 459.616,36 hektar. Lahan di Kutai Timur itu melampaui lahan perkebunan sawit di 56
Kabupaten Paser yang telah terlebih dulu mengembangkan kelapa sawit yang memiliki lahan 181.503,25 hektar.Kawasan sawit yang luas lainnya terdapat di Kabupaten Kutai Kartanegara mencapai 224.223,15 hektar disusul Kutai Barat 146.304,81 hektar. Berikutnya, Kabupaten Berau seluas 123.389,50 hektar dan Penajam Paser Utara (PPU) 52.291.18 hektar serta Mahakam Ulu memiliki luas 19.926 hektar.

Sementara itu kawasan terkecil terdapat di wilayah kota seperti Balikpapan yang hanya memiliki 33 hektar sedangkan Bontang 52 hektar dan Samarinda seluas 1.358 hektar. Pengembangan komoditi kelapa sawit terus didorong oleh Pemerintah Provinsi Kaltim.Selain perusahaan besar swasta (PBS) dan perusahaan besar negara (BUMN) juga memberdayakan masyarakat yang memiliki lahan-lahan tidak termanfaatkan agar ditanami (Sekretariat Provinsi Kalimantan Timur, 2018).

Menurut Fauzi(2004), sejalan dengan semakin meningkatnya produksi kelapa sawit dari tahun ke tahun, di sisi lain akan terjadi pula peningkatan volume limbahnya, baik berupa limbah padat maupun limbah cair. Limbah kelapa sawit adalah 
Vol. 8, No. 1, Oktober 2020

sisa-sisa hasil tanaman kelapa sawit yang tidak termasuk dalam produk utama atau merupakan hasil ikutan dari proses pengolahan kelapa sawit.

Limbah padat kelapa sawit dapat berupa tandan kosong, cangkang, janjang, dan fiber (sabut). Tandan kosong adalah rangka antar buah, sedangkan cangkang adalah kulit buah. Diantara cangkang terdapat serabut yang disebut fiber. Limbah yang dihasilkan dari industri pengolahan kelapa sawit antara lain janjang kosong, limbah cair, limbah solid (padatan) dan cangkang (Pardamean, 2008).

Kelapa sawit untuk tumbuh dan berkembang dibutuhkan perawatan yang intensif dari petaninya. Selain pembersihan tanaman liar di sekitar pohon kelapa sawit, pembersihan pelepah kelapa sawit yang akan maupun yang sudah kering/mati perlu dilakukan untuk meningkatkan produktivitas dari buah kelapa sawit. Selama ini pemanfaatan pelepah kelapa sawit digunakan untuk pakan ternak atau untuk kayu bakar. Pemanfaatan akan pelepah kelapa sawit sebagai limbah menjadi sesuatu yang bernilai ekonomis dapat dilakukan dengan berbagai cara.Salah satu caranya adalah pemanfaatan limbah pelepah kelapa sawit menjadi raw material untuk pembuatan produk fungsional. Setelah dilakukan proses pengolahan limbah pelepah kelapa sawit mulai dari pembahanan sampai pembuatan produk, maka dapat disimpulkan bahwa limbah pelepah kelapa sawit dapat diolah menjadi bahan dasar pembuatan produk fungsional salah satunya adalah aksesoris interior baik produk dua dimensi seperti kerai maupun produk tiga dimensi seperti produk pewadahan (Andansari dkk, 2013).

Namun, pengembangan pemanfaatan pelepah kelapa sawit untuk produk yang lain masih terbuka, salah satunya adalah aksesoris interior dengan proses dianyam.

Dari latar belakang di atas dapat dilihat bahwa masih terbuka peluang untuk mengembangkan pemanfaatan limbah pelepah kelapa sawit menjadi produk lain dengan melalui proses dianyam untuk pembuatan produk fungsional berupa aksesoris interior.

\subsection{Rumusan Masalah}

Adapun Rumusan Masalah dalam Penelitian ini adalah:

1. Bagaimana mendesain produk alternatif berbahan limbah pelepah kelapa sawit

2. Bagaimana mendesain produk alternatif berupa aksesoris interior berbahan limbah pelepah kelapa sawit yang memiliki nilai estetis khas Kalimantan Timur

\subsection{Tujuan Khusus :}

Tujuan penelitian yang ingin dicapai adalah 1. Merancang produk alternatif berbahan limbah pelepah kelapa sawit dengan proses dianyan

2. Merancang alternatif berupa aksesoris interior berbahan limbah pelepah kelapa sawit yang memiliki nilai estetis khas Kalimantan Timur

\section{METODE}

\subsection{Observasi}

Observasi dilakukan agar dapat menemukan permasalahan yang ada di lingkungan sekitar dan mengetahui permasalahan apa yang dapat diselesaikan sebagai tujuan akhir dari perancangan produk. Setelah dilakukannya observasi, ditemukanlah masalah mengenai produk ini yaitu produk aksesoris interior dari anyaman limbah pelepah kelapa sawit. Lalu dilakukan pengumpulan data dengan metode wawancara, referensi agar mendapat informasi mengenai keadaan lapangan dan kebutuhan pengguna nantinya untuk produk ini.

\subsection{Perumusan Masalah}

Setelah ditemukan permasalahan, dibutuhkanlah penyelesaian dan data dari wawancara. Didapatkan hasil berupa keadaan lapangan serta kebutuhan pengguna yang harus dipenuhi. Dari situ dirumuskanlah permasalahan yang membutuhkan 
Al Issya Suci Rachmawati, Dita Andansari, Pengembangan Aplikasi Material Limbah Pelepah Kelapa Sawit Untuk Produk Aksesoris Interior

solusi yang nantinya solusi tersebut dituangkan pada perancangan produk.

\subsection{Studi Pustaka}

Studi pustaka dilakukan dengan mengumpulkan data dari berbagai sumber literatur, jurnal ilmiah, dan lain-lain guna menemukan data serta informasi terkait hal apa saja yang dibahas dalam pembuatan produk. Maka dari itu dalam perancangan produk ini dilakukan studi pustaka terhadap berbagi informasi mengenai meja tamu.

\subsection{Analisis}

Setelah itu dilakukan analisis terhadap permasalahan dari data dan informasi yang sudah dikumpulkan. Analisis dilakukan guna memberi petunjuk mengenai produk seperti apa yang dibutuhkan oleh pengguna.

\subsection{Alternatif Desain dan Analisis Alter- natif}

Alternatif desain dibuat sebagai pilihan solusi untuk masalah desain produk yang dirancang dan hasil akhirnya dibuatlah prototype. Alternatif desain akan dianalisis kelebihan dan kekurangannya sehingga terpilih satu desain yang dinilai dapat menjadi penyelesaian masalah dan mampu memenuhi kebutuhan pengguna.

\subsection{Pengembangan Desain Terpilih}

Desain yang telah dipilih dari alternatif dikembangkan lagi hingga dapat menjadi produk yang maksimal. Pengembangannya dapat berupa bentuk, warna, sistem, maupun elemen produk sesuai dengan analisis yang telah dilakukan. Perkembangan terhadap desain yang terpilih hanya mengganti sebagian desain awal karena perkembangan dilakukan sebagai penyempurnaan produk agar dapat memenuhi kebutuhan pengguna dengan maksimal.

\subsection{Modeling}

Modeling merupakan perancangan produk yang dibuat sesuai dengan gambar awal. Model biasanya dibuat dengan skala tertentu.

\subsection{Pembuatan Gambar dan Prototype}

Gambar yang dibuat sebelum pembuatan prototype adalah gambar teknik produk yang mampu menjelaskan bagaimana spesifikasi serta sistem dan gambar produk dengan lebih rinci. Setelah dibuat gambar fungsional, dibuatlah prototype menggunakan skala 1:1 dan fungsionalnya. Pembuatan prototype disesuaikan dengan desain yang telah dikembangkan berdasarkan dengan analisis yang telah dilakukan.

Menurut perancangan Vinod Goel (1995) agar perancangan lebih terarah, maka dibuatlah metode perancangan jam lampu dari pemanfaatan limbah pelepah kelapa sawit seperti tampak pada gambar no 1 .

\section{PEMBAHASAN}

\subsection{Analisis Pasar}

Analisis pasar dilakukan agar produsen suatu produk dapat menganalisa dan menentukan peluang-peluang pasar yang dapat ditembus sehingga akan didapatkan sasaran konsumen yang tepat. Analisis pasar mencakup lokasi atau letak dipasarkannya suatu produk, misalnya seberapa luas ruang lingkup pasar, strategi atau setidaknya lokasi yang dipilih terhadap sasaran konsumen maupun sasaran distributor produk, serta perusahaan pesaing yang mungkin memasarkan produk yang sama. Selain itu yang paling utama adalah meninjau sasaran konsumen yang tepat sehingga pemasaran dapat mudah berjalan dan berkembang.

\section{a. Segmentasi Geografis}

Untuk desain aksesoris interior berupa jam lampu, segmentasi geografi yang ditentukan adalah wilayah Indonesia terutama di wilayah Provinsi Kalimantan Timur di daerah perkotaan yang masyarakatnya 


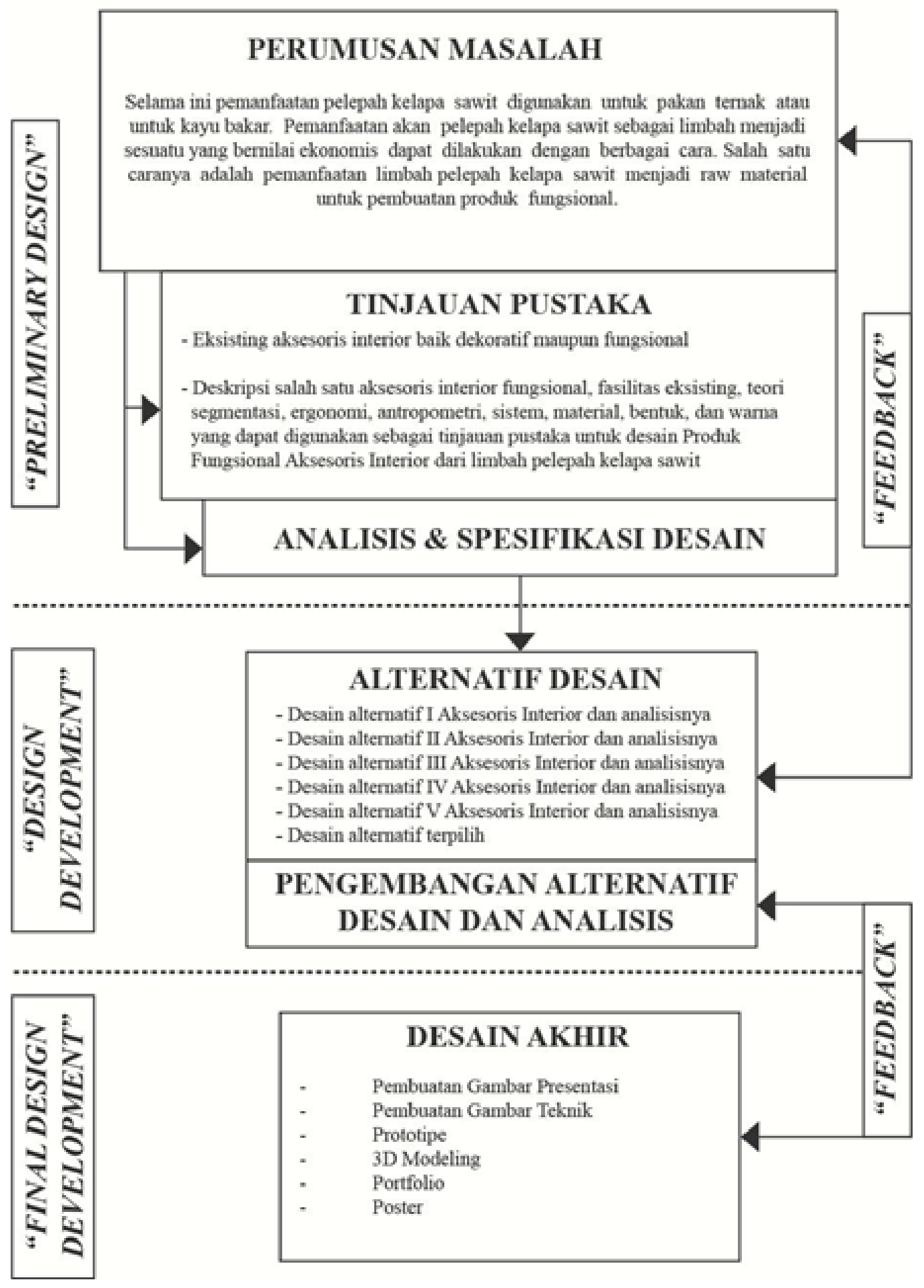

Gambar 1. Metode penelitian 
Al Issya Suci Rachmawati, Dita Andansari, Pengembangan Aplikasi Material Limbah Pelepah Kelapa Sawit Untuk Produk Aksesoris Interior

memiliki aktifitas cukup padat dan membutuhkan kemudahan.

\section{b. Segmentasi Demografis}

Berdasarkan demografi, target pasar produk fungsional aksesoris interior jam lampu dapat dibagi berdasarkan gender pengguna produk tersebut. Berdasarkan gender, pengguna produk fungsional aksesoris interior jam lampu ini didesain untuk pengguna berjenis kelamin laki-laki dan perempuan atau unisex. Karena produk merupakan aplikasi ekplorasi material sehingga yang ditekankan adalah eksplorasi materialnya dan bukan fungsinya, maka target pasar untuk sementara ini ditujukan untuk usia 30 tahun ke atas.

\section{c. Segmentasi Psikografis}

Segmentasi psikografis ditujukan pada seseorang yang menyukai kerajinan dekorasi dan penataan ruang, serta memiliki kegiatan yang aktif.

\section{d. Segmentasi Perilaku}

Segmentasi perilaku ditujukan untuk anak muda dari kalangan menengah hingga kalangan menengah ke atas.

\section{e. Segmentasi Manfaat}

Berdasarkan manfaat, target pasar mebel aksesoris interior jam lampu ini dapat dibagi berdasarkan manfaat utama produk dan tipe pengguna yang mencari tiap-tiap manfaat mebel aksesoris interior jam lampu tersebut.

Berdasarkan manfaat utama, aksesoris interior jam lampu ini didesain sebagai penunjuk waktu yang fungsional saat digunakan untuk tidur ketika malam hari sehingga mempengaruhi target konsumen yaitu dalam menjadikan lampu tidur. Selain itu, produk ini juga didesain untuk dijadikan sebagai aksesoris interior atau penghias maupun pelengkap dekorasi ruangan. Berdasarkan tipe pengguna, produk aksesoris interior jam lampu ini didesain untuk pengguna yang menyukai dekorasi ruangan serta memiliki kegiatan yang aktif.

\subsection{Studi Aktivitas dan Kebutuhan}

Analisis aktivitas dan kebutuhan dilakukan untuk mengetahui aktivitas yang dilakukan berkaitan dengan produk yang akan dibuat sehingga diperoleh kebutuhan pengguna. Berdasarkan kebutuhan tersebut maka dibuat pemecahan untuk memenuhi kebutuhan yang dapat diaplikasikan pada produk.

Pada laporan ini, kami mengambil data dengan menggunakan kuisioner, yaitu dengan memberikan beberapa pertanyaan kepada responden mengenai kebutuhan produk yang akan diinovasikan. Setelah pengambilan data dengan kuisioner pertanyaan, kami mengidentifikasikan apa yang menjadi kebutuhan responden. Cara identifikasi kebutuhan konsumen yang digunakan adalah dengan menyebarkan kuisioner ke 30 responden. Hasil yang didapatkan dari kuisioner tersebut antara lain :

a. Aksesoris interior yang akan dibuat sebagai produk fungsional adalah jam, karena $93 \%$ orang memiliki jam sebagai penunjuk waktu dan memilih jam lampu berbentuk jam meja.

b. Karena produk merupakan aplikasi dari eksplorasi material limbah pelepah kelapa sawit dan material kombinasi, sehingga yang ditekankan adalah eskplorasi materialnya bukan dari fungsinya, maka target usia untuk sementara di tujukan untuk 30 tahun ke atas.

c. Fasilitas yang harus dimiliki oleh produk jam ini adalah lampu tidur, karena $80 \%$ orang biasanya mematikan lampu ketika tidur dan harus menyalakan lampu terlebih dahulu untuk melihat jam.

d. Produk jam ini harus memiliki tampilan yang menarik dan estetis karena $80 \%$ orang menjadikan jam sebagai penghias ruangan.

Dari survey yang dilakukan, maka didapatkan aktifitas dan kebutuhan orang-orang dari produk tersebut, antara lain adalah : 
Vol. 8, No. 1, Oktober 2020

Tabel 1. Studi Aktivitas dan Kebutuhan

\begin{tabular}{|c|c|c|c|c|}
\hline No. & Altivitas & Pecralstan & Kebutihn & Usuran \\
\hline 1. & $\begin{array}{l}\text { Malihst wolkn pada } \\
\text { jam }\end{array}$ & $\begin{array}{l}\text { Jarme porngivk } \\
\text { waltu }\end{array}$ & 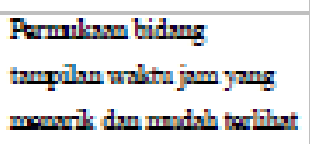 & $\begin{array}{l}\text { Jarum jam : } 3 \mathrm{~cm} \\
\text { Jarum Mont : } 4 \mathrm{~cm} \\
\text { Jarum datis : } 5 \mathrm{~cm}\end{array}$ \\
\hline 2. & $\begin{array}{l}\text { Mangganti baterai } \\
\text { jom leatilka bateni } \\
\text { hobis }\end{array}$ & $\begin{array}{l}\text { Merin jam don } \\
\text { baterai jam }\end{array}$ & $\begin{array}{l}\text { Rung unt: meosupotion } \\
\text { mokin jam }\end{array}$ & $\begin{array}{l}\text { Uhann merim jam } \\
\text { Pajimg : } 5,6 \mathrm{~cm} \\
\text { Iabor : } 1,5 \mathrm{~cm} \\
\text { Trnggi: } 5,5 \mathrm{~cm}\end{array}$ \\
\hline 3. & $\begin{array}{l}\text { Mangguvan } \\
\text { longu poda jam } \\
\text { sbagi rumber } \\
\text { penerangn }\end{array}$ & Lampu IND & $\begin{array}{l}\text { Rung unt: meosngotion } \\
\text { langn IFD }\end{array}$ & 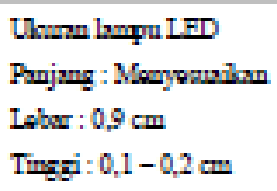 \\
\hline 4. & 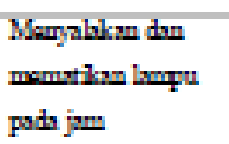 & Adoptor & $\begin{array}{l}\text { lahr wits meosngation } \\
\text { label adyptor }\end{array}$ & Labsr $: 0,5-1 \mathrm{~cm}$ \\
\hline 5. & $\begin{array}{l}\text { Malataldam jam di } \\
\text { majz }\end{array}$ & $\begin{array}{l}\text { Paryange / alss } \\
\text { jam }\end{array}$ & 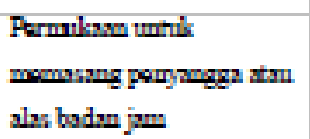 & Panjing : $5-10 \mathrm{~cm}$ \\
\hline
\end{tabular}

Sumber : dokumentasi pribadi

Berdasarkan analisis aktivitas dan kebutuhan yang terdapat pada tabel serta keterangan di atas, maka telah didapatkan kesimpulan mengenai komponen-komponen apa saja harus ada dalam produk. Berikut fasilitas yang terdapat produk, ialah

a. Memiliki tampilan visual yang menarik agar waktu mudah terlihat

b. Memiliki ruang untuk meletakkan mesin jam yang mudah dijangkau agar mudah saat penggantian baterai jam

c. Memiliki ruang untuk memasang lampu pada jam sebagai sumber penerangan

d. Memiliki ruang atau jalur kabel penghubung lampu pada jam yang mudah dijangkau untuk menyalakan dan mematikan lampu

e. Memiliki badan, alas, atau penyangga yang kuat untuk jam agar tetap berdiri dan tidak mudah jatuh saat diletakkan di atas meja

\subsection{Analisis Ergonomi dan Antropome-} tri

Tujuan dibuatnya analisis ergonomi ialah mengetahui produk sudah aman dan nyaman ketika digunakan.Selain itu, analisis ergonomi juga bisa untuk menyesuaikan suasana kerja dengan aktivitas manusia \& lingkungannya. Berikut adalah beberapa analisis ergonomi yang didapatkan pada produk Jam Lampu dari pemanfaatan limbah pelepah kelapa sawit antara lain :

a. Karena limbah yang akan dibuat dengan cara di anyam, maka anyaman limbah pelepah kelapa sawit tidak boleh terdapat sisi yang tajam atau bergerigi agar tidak melukai pengguna ketika dipegang.

b. Produk ini berfungsi sebagai penunjuk waktu dan lampu tidur, maka warna dari jarum jam tidak boleh sama dengan warna pelepah kelapa sawit sebagai badan jam agar jarum dapat terlihat dengan jelas. Sedangkan lampu yang digunakan tidak boleh terlalu terang karena berfungsi sebagai lampu tidur, 
Al Issya Suci Rachmawati, Dita Andansari, Pengembangan Aplikasi Material Limbah Pelepah Kelapa Sawit Untuk Produk Aksesoris Interior

tetapi juga tidak boleh terlalu redup agar jarum jam tetap terlihat.

Analisis anthropometri digunakan untuk mengukur kenyamanan dari sebuah produk.Dengan adanya kenyamanan dalam sebuah produk maka produk tersebut sudah bisa di produksi, jika sebuah produk tidak nyaman digunakan, maka produk tersebut gagal dan tidak bisa di produksi.

Analisis juga dilakukan untuk mendapatkan susunan tiap-tiap komponen atau fasilitas yang akan diterapkan kedalam produk. Dalam hal ini, anthropometri yang berkaitan dengan produk yang akan dirancang ialah :

a. Dimensi dari anyaman pelepah kelapa sawit yang dijadikan badan jam lampu menyesuaikan hasil anyaman dan ukuran panjang tangan, yakni kurang lebih $15-18 \mathrm{~cm}$.

b. Jika menggunakan penyangga belakang, penyangga harus menghasilkan kemiringan kurang lebih 50 terhadap badan jam dari sudut normal agar jam dapat berdiri sempurna dan tidak mudah jatuh ketika diletakkan dimeja. Tetapi jika menggunakan penyangga tunggal, maka harus memiliki tumpuan dibagian bawah penyangga yang lebarnya berukuran kurang lebih $5-10 \mathrm{~cm}$.

\subsection{Analisis Konfigurasi}

Analisis konfigurasi dilakukan untuk mendapatkan susunan atau konfigurasi dari tiap-tiap komponen pada produk. Adapun komponen yang terdapat pada jam lampu tersebut antara lain :

a. Badan atau jam berbahan dasar pelepah kelapa sawit yang dianyam lalu ditempelkan pada material kombinasi berupa kayu ulin.

b. Jarum jam

c. Mesin jam dinding

d. Lampu LED strip

e. Adaptor

\subsection{Analisis Sistem}

Analisis sistem perlu dilakukan untuk mengetahui sistem apa yang saja diperlukan pada produk agar dapat berfungsi secara benar tanpa mengurangi kenyamanan produk. Berikut analisis dari sistem yang digunakan pada produk:

\section{a. Sistem Konstruksi Rangka pada Badan Jam Lampu}

Sistem sambungan konstruksi dapat diaplikasikan pada produk aksesoris interior jam lampu, maka sistem yang ada antara lain; butt joints, dan mortise \& tenon joints. Diantara sistem-sistem sambungan konstruksi tersebut harus dipilih salah satunya melalui analisis yang mempertimbangkan aspek-aspek lainnya sebagai item penilai yakni kekuatan : yang dimaksud kekuatan adalah kemampuan sistem konstruksi memberi kekuatan pada rangka produk agar tidak mudah terlepas/rusak; kemudahan pengerjaan : yaitu kemampuan sistem konstruksi tersebut mudah untuk dikerjakan terhadap produk; kerapihan : yakni kemampuan sistem konstruksi memberikan tampilan yang rapi terhadap rangka produk, dan kesesuaian konsep : yakni sistem sambung sesuai dengan konsep tangkai yang akan dirancang terhadap produk. Berikut analisis dari sistem konstruksi untuk rangka badan jam lampu :

Dari analisis diatas terpilih sistem sambungan konstruksi Mortise \& Tenon Jointsyang akan digunakan pada rangka badan jam lampu karena sistem yang dibutuhkan memenuhi semua aspek penilaian dan serta diharapkan mampu menopang seluruh komponen produk.

\section{b. Sistem Sambungan Rekat untuk Rangka Badan Jam Lampu}

Dari sistem sambungan rekat jam lampu, terdapat tiga jenis sistem sambungan rekat antara lain; sambungan lem, sambungan paku, dan sambungan sekrup. Dalam analisis sistem sambungan rekat tersebut memerlukan pertimbangan melalui as- 
Vol. 8, No. 1, Oktober 2020

pek-aspek yang menjadi item penilai yakni kekuatan : yaitu kemampusan sistem rekat dapat memberikan kekuatan terhadap konstruksi rangka produk tersebut agar lebih kuat dan tidak mudah rusak/terlepas; kemudahan pengerjaan : yaitu kemampuan sistem sambungan memudahkan dalam pengerjaan produk; dan kerapihan : yakni kemampuan sistem sambungan memberikan hasil akhir yang rapi, tidak membuat kotor, dan tidak mengganggu penampilan produk. Berikut analisis dari sistem sambungan rekat untuk rangka badan jam lampu:

Dari analisis diatas terpilih sistem sambungan rekat yang akan digunakan pada rangka badan jam lampu adalah sambungan lem, karena konstruksi rangka akan dibuat secara permanen dan tidak dapat dibongkar pasang sehingga kekuatan dari produk lebih terjaga.

\section{c. Sistem Penggerak Jam}

Jam membutuhkan mesin penggerak sebagai penunjuk waktu. Sistem penggerak jam yang dapat diaplikasikan pada jam lampu sebagai penunjuk waktu antara lainQuartz Movement, dan Digital Movement. Dintara sistem penggerak jam tersebut harus dipilih salah satunya melalui analisis yang mempertimbangkan aspek-aspek lainnya sebagai item penilaian yakni kemudahan penggunaan : yang dimaksud kemudahan penggunaan yaitu kemampuan sistem penggerak jam memiliki tampilan yang umum sehingga dapat dimengerti oleh pengguna dan kemudahan dalam perawatan; kemudahan perakitan : yakni kemampuan sistem penggerak jam lebih mudah dirakit atau dipasang secara manual ketika akan digunakan. Berikut analisis dari jenis sistem penggerak jam:

Dari analisis diatas, terpilih mesin dengan sistem penggerak waktu yang akan digunakan pada jam lampu. Mesin jam jenis quartz movement dipilih sebagai sistem penggerak waktu untuk jam lampu karena mesin jam jenis quartz movement mudah didapatkan dan mudah dirakit sendiri se- cara manual. Mesin jam quartz movement juga memiliki tampilan yang umum sehingga mudah dimengerti oleh pengguna dan memiliki pengaturan waktu yang mudah. Berikut kesimpulan dari analisis sistem yang telah dilakukan:

1. Sistem Struktur dan Konstruksi Sistem konstruksi: Mortise \& Tenon Joints

2. Sistem sambungan rekat: sambungan lem

3. Sistem Hardware

4. Sistem penggerak jam: mesin quartz movement

\subsection{Analisis Material}

Analisis bentuk digunakan untuk memilih bentuk jenis apa yang akan diaplikasikan pada produk. Karena segmentasi pasar yang dituju adalah anak muda yang memiliki kegiatan aktif seperti kuliah maupun bekerja yang menyukai penataan ruang serta kemudahan. Sehingga perilaku tersebut mempengaruhi gaya hidup masyarakat yang berada di perkotaan saat ini dengan tingkat aktifitas yang cukup tinggi. Orang-orang tersebut cenderung memilih atau menggunakan desain yang sederhana tetapi menarik. Karena perancangan produk dari limbah pelepah kelapa sawit ini dengan caradi anyam, maka desain tersebut dapat dihadirkan dari berbagai bentuk dasar yang dihasilkan pola anyaman.

Dari alternatif-alternatif pendekatan bentuk dasar yang telah coba dilakukan untuk menganyam limbah pelepah kelapa sawit, maka didapatkan beberapa bentuk dasar yang terlihat dari pola anyaman antara lain bentuk kotak/persegi dari anyaman dengan pola vertikal-horizontal, bentuk bintang segienam dari anyaman dengan pola bintang, dan bentuk bunga dari anyaman dengan pola melingkar.

Pada jenis anyaman dengan pola vertikal-horizontal yang menghasilkan bentuk kotak/persegi lebih mudah untuk dibuat, tetapi hasilnya kurang menarik dan terkesan monoton karena hanya menghasilkan dua 
Al Issya Suci Rachmawati, Dita Andansari, Pengembangan Aplikasi Material Limbah Pelepah Kelapa Sawit Untuk Produk Aksesoris Interior

arah anyaman dan kurang banyak menghasilkan motif.Jika anyaman ini dilem, hasilnya kurang rapi.

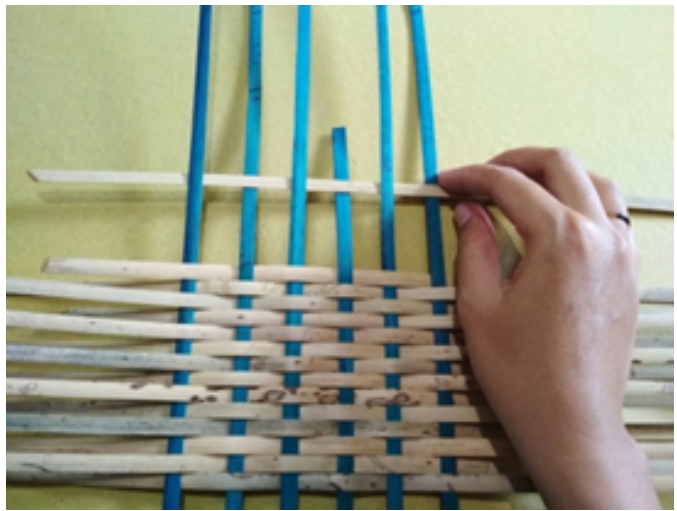

Sumber : dokumentasi pribadi, 2019

Gambar 2. Analisis Bentuk Anyaman Persegi

Untuk jenis anyaman dengan pola bintang segienam tingkat kerumitannya sedang. Pada anyaman ini terdapat 2 sisi yang dapat menghasilkan 2 motif berbeda dalam 1 anyaman yakni pada bagian depan akan membentuk motif bintang sedangkan dibagian belakang akan terlihat motif segienam, sehingga jenis anyaman dengan pola bintang lebih menarik karena memiliki motif yang lebih bervariasi dibandingkan dengan pola vertikal-horizontal. Jika jenis anyaman ini dilem untuk merekatkan bilah-bilahnya, hasilnya kurang rapi.
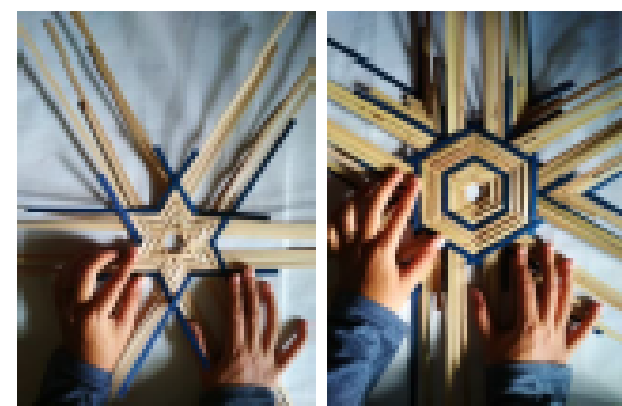

Sumber : dokumentasi pribadi, 2019 Gambar 3 Analisis Bentuk Anyaman Bintang Segi Enam
Jenis anyaman dengan pola meling-

kar memiliki tingkat kerumitan yang sedang. Motif yang didapatkan pada jenis anyaman ini antara lain motif segitiga, segi lima, dan seterusnya tergantung berapa banyak bilah yang digunakan. Ukuran anyaman ini juga tergantung banyaknya bilah yang dianyam, semakin banyak bilah digunakan maka semakin besar anyaman yang dihasilkan.Pada pola jenis ini, bentuk yang dihasilkan terlihat sederhana namun memiliki tampilan yang cukup menarik.Jenis anyaman dengan pola ini juga menghasilkan anyaman yang cukup kuat dan tidak mudah bergeser bilahnya, sehingga penggunaan lem hanya perlu dibagian ujung saja dan tidak merusak penampilan anyaman.
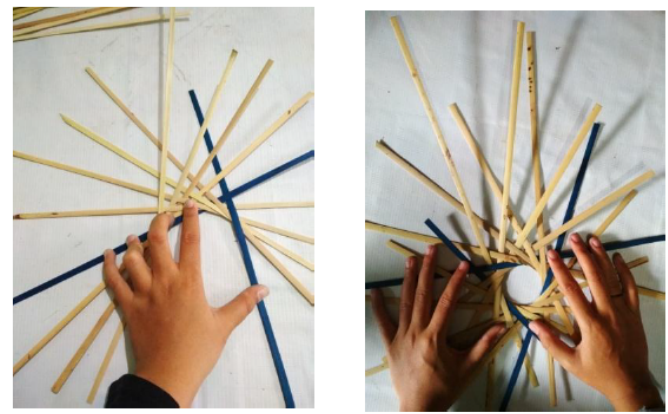

Sumber : dokumentasi pribadi, 2019 Gambar 4. Analisis Bentuk Anyaman Melingkar

Berdasarkan analisa diatas, maka pendekatan bentuk dasar dari pola anyaman yang digunakan yaitu jenis anyaman melingkar yang membentuk pola lingkaran. Dimana pola jenis ini memiliki tingkat kerumitan yang sedang.Bentuknya sederhana namun menarik.Jenis pola ini juga paling rapi diantara pola lainnya ketika di lem dan permukaannya lebih rata.

\subsection{Analisis Warna}

Analisis warna diperlukan untuk guna menentukan warna yang sesuai untuk diaplikasikan pada aksesoris interior jam lampu sebagai warna aksentuasi pada produk. Pendekatan yang digunakan dalam 
Vol. 8, No. 1, Oktober 2020

analisis ini adalah hubungan warna dengan psikologi pengguna produk dan memberikan kualitas tidur yang baik. Adapun analisis warna yang dilakukan adalah sebagai berikut :

Alternatif warna yang disukai seorang anak muda pascaremaja adalah warna biru, warna hijau, dan warna merah.Sedangkan warna-warna yang memberikan pengaruh paling baik terhadap kualitas tidur adalah warna biru, warna kuning, warna hijau, dan warna jingga.Berdasarkan analisis dari kedua pendekatan tersebut, dapat diketahui bahwa warna biru menduduki posisi teratas untuk warna yang paling disukai anak muda dan memberikan kualitas tidur paling baik. Karena pertimbangan tersebut, maka warna yang dipilih sebagai warna aksentuasi untuk produk aksesoris interior jam lampu adalah warna biru, sedangkan warna dominasi dari produk adalah warna natural dari material utama yaitu pelepah kelapa sawit dan material kombinasi yaitu kayu ulin.

\subsection{Spesifikasi Desain}

Dapat disimpulkan dari data yang telah di analisis sebelumnya. Maka didapatkan hasil akhir untuk produk dengan kriteria sebagai berikut :

A. Pengguna

1. Laki-laki dan perempuan

2. Diutamakan 30 tahun ke atas

3. Menyukai dekorasi ruangan dan memiliki kegiatan yang aktif

B. Dimensi

1. Dimensi keseluruhan badan jam: 15 $18 \mathrm{~cm}$

C. Komponen

1. Ruang pada bagian depan jam untuk menempatkan jarum jam dan lampu LED strip.

2. Ruang pada bagian belakang untuk mesin jam
D. Konfigurasi

- Alternatif Konfigurasi 4

E. Sistem

1. Sistem konstruksi : Mortise \& Tenon Joints

2. Sistem sambungan rekat: Lem

3. Sistem penggerak jam/jenis mesin jam: Mesin jam dinding quartz movement

F. Material

1. Limbah pelepah kelapa sawit

2. Limbah kayu ulin dengan ketebalan

G. Bentuk

- Bentuk pola anyaman melingkar

H. Warna

1. Warna dominan adalah warna alami bahan limbah pelepah kelapa sawit dan kayu ulin.

2. Warna aksentuasi adalah warna biru.

Desain Akhir

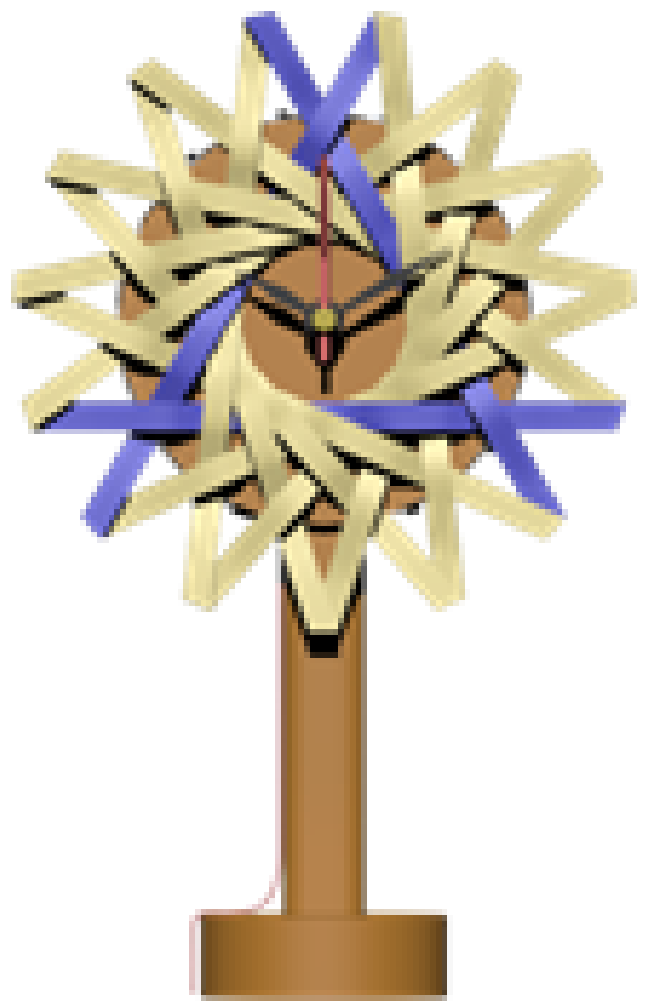

Gambar 5 Gambar 3D Modeling 
Al Issya Suci Rachmawati, Dita Andansari, Pengembangan Aplikasi Material Limbah Pelepah Kelapa Sawit Untuk Produk Aksesoris Interior

IV. Kesimpulan

Simpulan dari hasil "Pengembanfaatan limbah pelepah kelapa sawit tersebut. gan Aplikasi Material Limbah Pelepah Kelapa Sawit untuk Produk Aksesoris Interior“ ialah sebagai berikut :

1. Dalam perancangan produk dari limbah pelepah kelapa sawit ini didapatkan hasil bahwa pelepah kelapa sawit selain dapat ditenun juga dapat dianyam dengan beberapa pola, baik pola anyaman dasar maupun pola dengan bentuk tertentu.

2. Meskipun bobotnya lebih barat, limbah pelepah kelapa sawit yang masih segar lebih mudah disigar dan dikerik, selain itu karena pelepah segar masih memiliki kandungan air, pelepah segar kelenturannya cukup tinggi dan tidak patah saat dibengkokkan atau ditekuk sehingga perlakuan terhadap pelepah yang masih segar akan lebih mudah seperti penganyaman. Namun jika sudah kering, kandungan air dalam pelepah sudah berkurang maka pelepah akan mengeras dan kaku sehingga perlu tenaga lebih dalam perlakuannya seperti saat pembilahan, pengerikan dan penganyaman, tetapi bobotnya menjadi lebih ringan.

\section{Saran}

Saran yang dapat diberikan bagi para produsen dan desainer adalah melakukan eksplorasi lanjutan, menganalisa kembali sifat dan karakteristik dari limbah pelepah kelapa sawit, baik yang masih segar maupun yang sudah kering. Eksplorasi tentang jenis kerajinan dari bahan yang telah banyak dilakukan seperti bahan rotan maupun bambu yang kemudian dapat diterapkan pada pelepah kelapa sawit juga diperlukan sehingga pelepah kelapa sawit menjadi alternatif bahan yang dapat digunakan sebagai bahan baku pembuatan produk tertentu sehingga dapat meningkatkan nilai jual dari limbah pelepah kelapa sawit itu sendiri sebagai solusi mengurangi limbah yang terbuang percuma dan meningkatkan kreatifitas masyarakat terhadap peman- 
Vol. 8, No. 1, Oktober 2020

\section{DAFTAR PUSTAKA}

Akmal, Imelda. (2013) Seri Rumah Ide Edisi 9/V: Cermin Interior hal. 22. Jakarta : Gramedia Pustaka.

Anggraeni, Rani. (2009). Simple Interior Makeover: hal 53. Jakarta : PT. Gramedia Pustaka Utama.

Departemen Pendidikan Nasional. (1999). Kamus Besar Bahasa Indonesia

Eddy S. Marizar. (2005). Designing Furniture : Teknik Merancang Mebel KreatifKonsepsi, solusi, inovasi dan Implentasi. Yogyakarata : MediaPressindo.

Fauzi, Y. (2004). Kelapa Sawit. Edisi Revisi, Penebar Swadaya, Jakarta.

Martawijaya, Abdurrahim, dkk. (2005). Atlas Kayu Indonesia Jilid I: hal 20, 21, 22, 85, 88, 146, 147 \& 148.Bogor : Departemen Kehutanan Badan Penelitian dan Pengembangan Kehutanan.

Pahan, I. (2006). Panduan Lengkap Kelapa Sawit, Penebar Swadaya. Jakarta.

Pardamean, M. (2008). Panduan Lengkap Pengelolaan Kebun dan Pabrik Kelapa Sawit: halaman 15.Jakarta: Agromedia Pustaka.

Pepis, Betty. 1965. Interior Decoration A to Z

Pratiwi, Ariani, dkk. (2013). 32 Lemari Dua Sisi: hal 31. Jakarta/Depok : Griya Kreasi (Penebar Swadaya Grup).

Vinod G. (1995).Sketches of througt.MIT PRESS : USA.

Wicaksono, Andie, A., dkk. (2014). Teori Interior: hal. 9-10. Jakarta Timur : Griya Kreasi (Penebar Swadaya Grup).

Andansari, Dita, dkk. (2013). PEMANFAATAN LIMBAH PELEPAH KELAPA SAWIT UNTUK BAHAN DASAR PEMBUATAN PRODUK FUNGSIONAL BERGAYA ETNIK DAYAK DI KALIMANTAN TIMUR. SEMINAR NASIONAL ke 8 : Rekayasa Teknologi Industri dan Informasi.

Honggowidjaja, S. P. (2003).MENYADARI POTENSI AKSESORIS DALAM UPAYA PENGHADIRAN SEBUAH TEMPAT129-130 \& 135. Jurusan Desain Interior,

Fakultas Seni dan Desain : Universitas Kristen Petra.

Haji, A. G. (2013).Jurnal Rekayasa Kimia dan Lingkungan Vol. 9, No. 3, hal.110, Komponen Kimia Asap Cair Hasil Pirolisis Limbah Padat Kelapa Sawit.Banda Aceh.

Willy, Deny. (2007).Merintis Klaster Baru Industri Kerajinan Dahan Salak Sebagai Upaya Preservasi Perkebunan Salak Cineam.Tasikmalaya : Insentif Ristek RI 2007.

\section{Webtografi}

Anjani, Rahmi. (4 Apr 2016 09:26 WIB). 11 Warna Kamar dan Pengaruhnya Terhadap Kebiasaan Tidur Anda. https:/wolipop.detik.com/home/d-3178825/11-warna-kamar-dan-pengaruhnya-terhadap-kebiasaan-tidur-anda. ( diakses 14 April 2019).

Ashish. (2016). HOW DOES A PENDULUM CLOCK WORK ?.https://www.scienceabc. com/innovation/pendulum-clock-works-escapement-ticking-sound-falling-weight. html.(diakses 16 April 2019).

Aulia, Fatka. (22 November 2017). Delapan Warna yang Mempengaruhi Kualitas Tidur. https://gedubar.com/1006-warna-yang-mempengaruhi-kualitas-tidur/) (diakses 16 April 2019).

Dekoruma, Kania. (1 Agustus 2016).Furniture 101: Kayu Solid, si Alami yang Menarik Hati!.https://www.dekoruma.com/artikel/9951/furniture-101-kayu-solid-si-alami- 
Al Issya Suci Rachmawati, Dita Andansari, Pengembangan Aplikasi Material Limbah Pelepah Kelapa Sawit Untuk Produk Aksesoris Interior

yang-menarik-hati. (diakses pada 20 Februari 2019).

Dekoruma, Kania. (27 Desember 2018).Apa Itu Kayu Bengkirai? Ini Dia Kelebihannya untuk Hunian.https://www.dekoruma.com/artikel/78620/apa-itu-kayu-bengkirai. (diakses pada 20 Februari 2019).

Jon, (4 agustus 2016). HOW DO QUARTZ CLOCK WORK. http://www.chelseaclock. $\mathrm{com} / \mathrm{blog} /$ how-do-quartz-clocks-work. ( diakses 16 April 2019).Fatma.Rangkaian Jam digital.http://elektronikadasar.info/rangkaian-jam-digital.htm. (diakses 16 April 2019).

Morgan, Eno. (21 Januari 2015).Sekilas Informasi Mengenai Kayu Jati Belanda : Kayu

Bekas Palet Impor. http://www.tokojatibelanda.com/informasi-tentang-kayu-jati-belanda/. (diakses 9 Maret 2019).

Royen, Abi. (12 April 2016). Berbagai Jenis Lampu LED dan Penjelasannya.http://abiblog.com/jenis-lampu-led-dan-penjelasannya/. (di akses pada 27 Desember 2018).

SEKRETARIAT PROVINSI KALIMANTAN TIMUR. (5 Maret 2018). Luas Perkebunan Sawit Kaltim 1,2 juta Hektar : (yans/sul/humasprov.http://disbun.kaltimprov. go.id/berita-1276-luas-perkebunan-sawit-kaltim-12-juta-hektar.html. (di akses pada Oktober 2018).

Suhud, Harris. (6 April 2018).Finishing Kayu dengan Vernis dan Mengenal Tingkat Kilapnya.https://custommebel.com/2018/04/06/finishing-kayu-dengan-vernis-dan-mengenal-tingkat-kilapnya/. (diakses pada 27 Maret 2019). .Manfaat dan Kelebihan Kayu Meranti, Kayu Khas Daerah Tropis.https:// www.dekoruma.com/artike1/70313/manfaat-dan-kelebihan-kayu-meranti. (diakses pada 20 Februari 2019). 